\title{
UPLATA NOVČANOG ULOGA ZA PREUZETE POSLOVNE UDJELE I PRAVNE POSLJEDICE NEUPLATE U DRUŠTVU S OGRANIČENOM ODGOVORNOŠĆU
}

UDK: 347.724

DOI: $10.31141 /$ zrpfs.2021.58.142.1165

Izvorni znanstveni rad

Primljeno: 01.04. 2021.

\begin{abstract}
Izmjenama i dopunama Zakona o trgovačkim društvima iz 2019. godine olakšana je uplata novčanih uloga za preuzete poslovne udjele u društvima s ograničenom odgovornošću. Prije upisa osnivanja društva u sudski registar svaki član društva mora uplatiti najmanje četvrtinu novčanog uloga za preuzeti poslovni udio, a ukupni iznos svih novčanih uplata ne može biti manji od jedne četvrtine temeljnog kapitala društva. Istodobno je određen i krajnji rok za uplatu ostatka novčanih uloga te je uvedena osobna i solidarna odgovornost članova koji nisu u cijelosti uplatili uloge za obveze društva do visine iznosa neuplaćenih uloga za sve poslovne udjele u društvu. Time se ograničava sloboda članova odrediti dospijeće obveze uplate novčanih uloga te se potire načelo neodgovornosti članova za obveze društva. Interesi se vjerovnika primjereno štite odredbama o unosu i očuvanju temeljnog kapitala društva, a posebno se štite ako bi smanjenjem imovine društva bilo ugroženo namirenje njihovih tražbina. U radu se obrađuju pravne posljedice nepravodobne uplate uloga i mjere koje društvo može poduzeti prema članu. Tim se mjerama osigurava uplata novčanih uloga za preuzete poslovne udjele. Vjerovnici mogu izravno namiriti svoje tražbine prema članovima društva samo u slučaju proboja pravne osobnosti, a posebice ako postoji materijalna potkapitalizacija društva.
\end{abstract}

Ključne riječi: društvo s ograničenom odgovornošću, uplata novčanog uloga, pravne posljedice neuplate uloga, proboj pravne osobnosti

\section{UVOD}

Temeljna je obveza članova društva s ograničenom odgovornošću uplata uloga za preuzete poslovne udjele pri osnivanju i naknadnom povećanju temeljnog kapitala društva. Ta obveza nastaje sklapanjem društvenog ugovora te traje do prestanka društva. Na temelju uplate uloga član društva stječe poslovni udio kao skup članskih prava i obveza, a oblikuje se temeljni kapital društva s ograničenom odgovornošću. Pritom članovi društva - osnivači društvenim ugovorom određuju visinu i vrstu uloga te dospijeće obveze, pridržavajući se odredbi članka 390. Zakona 
o trgovačkim društvima (u daljnjem tekstu: ZTD) ${ }^{1}$ o načinu uplate, odnosno unosa uloga prije upisa osnivanja društva u sudski registar.

Izmjenama i dopunama ZTD-a iz 2019. godine olakšana je uplata novčanih uloga za preuzete poslovne udjele sniženjem iznosa koji se mora uplatiti prije upisa osnivanja društva u sudski registar, ali je određen i krajnji rok za uplatu ostatka uloga, ako on nije u cijelosti uplaćen prije toga. Također se uvodi osobna i solidarna odgovornost članova društva koji nisu u cijelosti uplatili novčane uloge za obveze društva do visine iznosa neuplaćenih uloga za sve poslovne udjele u društvu. Time se ograničava sloboda članova društva odrediti dospijeće obveze uplate ostatka novčanog uloga za preuzete poslovne udjele te se odstupa od načela ograničene odgovornosti članova društava kapitala za obveze društva. Predviđenom izmjenom željelo se zaštititi vjerovnike društva, no ZTD poznaje druge pravne institute kojima se štite njihovi interesi. To su u prvom redu odredbe kojima se ostvaruje načelo unosa i održavanja temeljnog kapitala društva s ograničenom odgovornošću te proboju pravne osobnosti društva. Vjerovnici se iznimno štite ako bi smanjenjem imovine društva bilo ugroženo namirenje njihovih tražbina. ${ }^{2}$ Uplata novčanog uloga za preuzete poslovne udjele tiče se unutarnjeg odnosa članova i društva, što proizlazi iz odredbi ZTD-a o pravnim posljedicama ako dođe do zakašnjenja, odnosno izostanka uplate ostatka novčanog uloga za preuzete poslovne udjele.

\section{TEMELJNI KAPITAL I NAČELO OGRANIČENE ODGOVORNOSTI U DRUŠTVU S OGRANIČENOM ODGOVORNOŠĆU}

Osnovno je obilježje društava kapitala da imaju temeljni kapital, odnosno da se mogu valjano osnovati samo oblikovanjem najnižeg propisanog temeljnog kapitala. Taj se kapital oblikuje unosom uloga u novcu, stvarima ili pravima za preuzete poslovne udjele. Iznos se temeljnog kapitala u društvu s ograničenom odgovornošću određuje društvenim ugovorom, odnosno izjavom o osnivanju društva, pri čemu osnivači moraju voditi računa o najnižem propisanom iznosu temeljnog kapitala, ali uzimajući u obzir i potrebe društva za financijskim sredstvima sukladno djelatnostima koje će obavljati, a koje čine njegov predmet poslovanja. ${ }^{3}$ Temeljni kapital ima trojnu funkciju: a) predstavlja osnovu za određivanje opsega članskih prava i obveza koja ima pojedini član u društvu, uzimajući u obzir nominalni iznos

\footnotetext{
1 Zakon o trgovačkim društvima, Narodne novine, br. 111/1993, 34/1999, 121/1999, 52/2000, 118/2003, 107/2007, 146/2008, 137/2009, 125/2011, 152/2011, 111/2012, 68/2013, 110/2015, 40/2019.

2 Npr. pravo tražiti osiguranje za svoje nedospjele tražbine u slučaju redovitog smanjenja temeljnog kapitala ili priključenja društva, nevaljanost odricanja društva od zahtjeva za naknadu štete te nagodbe o šteti u slučaju odgovornosti članova društva i uprave za štetu pri osnivanju, odnosno vođenju poslova društva, zahtjev za naplatom tražbine prema članovima uprave, ako nisu postupali s dužnom pozornošću pri vođenju poslova društva, obveza povrata isplaćene dividende i sl.

3 Barbić, J., Pravo društava, Knjiga prva: Opći dio, Organizator, Zagreb, 2008., str. 157.
} 
njegovog poslovnog udjela, ${ }^{4}$ b) njime se osigurava pribavljanje imovine koja je potrebna društvu za obavljanje njegovih djelatnosti te c) predstavlja zapreku za nedopuštene isplate članovima društva, čime se štite vjerovnici. ${ }^{5}$

Društvo s ograničenom odgovornošću je samostalna pravna osoba koja ima vlastitu imovinu te njome odgovara za svoje obveze. Imovina društva čini njegovu aktivu pri čemu se njezina vrijednost mijenja tijekom poslovanja društva, a da to ne utječe na promjenu njegovog temeljnog kapitala. U pasivi se prikazuju izvori iz kojih potječe ta imovina, a pritom se razlikuje vlastiti i tuđi kapital. Vlastiti kapital društva čine ulozi članova u njegov temeljni kapital, rezerve kapitala i rezerve iz dobiti $^{6}$ te dobit društva. Radi se o sredstvima koje je društvo pribavilo od svojih članova i onima koja su nastala poslovanjem društva. Tuđi kapital čine ona sredstva koje je društvo pribavilo od trećih osoba i svojih članova te ih mora vratiti (krediti). Pritom društvo slobodno odlučuje o izvorima pribavljanja kapitala. ${ }^{7}$ Aktiva i pasiva prikazuju se u bilanci društva koja prikazuje njegov financijski položaj, odnosno sustavni pregled imovine, kapitala i obveza društva na određeni dan. Pravilima o unosu i održavanju temeljnog kapitala daje se sigurnost vjerovnicima društva da ono ima čime podmiriti njihove tražbine samo ako ima najmanje onoliku imovinu koja po vrijednosti odgovara temeljnom kapitalu pri osnivanju i tijekom poslovanja društva. ${ }^{8}$ Isplate su članovima moguće samo iz neto imovine društva ${ }^{9}$ čija vrijednost premašuje iznos temeljnog kapitala te je društvu zabranjeno vratiti uloge članova u temeljni kapital. ${ }^{10}$

4 Pritom se pojedinim članovima društva mogu društvenim ugovorom dati i neka posebna prava koje nemaju drugi članovi društva (čl. 409. st. 1. ZTD). 467.

5 Ivanjko, Š.; Kocbek, M; Prelič, S., Korporacijsko pravo, GV Založba, Ljubljana, 2009., str. 466.-

6 Društvo s ograničenom odgovornošću će imati te rezerve samo ako su predviđene društvenim ugovorom, odnosno ako postoje izvori iz kojih se pune rezerve kapitala (preuzimanje poslovnih udjela super pari, dodatne uplate za stjecanje posebnih prava u društvu, dodatne novčane i nenovčane činidbe, iznosi oslobođeni pojednostavnjenim smanjenjem temeljnog kapitala).

7 Društvo s ograničenom odgovornošću se u pravilu se ne obraća javnosti za pribavljanje potrebnog kapitala, već to čine članovi društva (nema sukcesivnog osnivanja društva). Imovina se društva može povećati tako da se društvenim ugovorom predvide obveze članova na ispunjavanje dodatnih novčanih i nenovčanih činidbi, odnosno da oni odluče o svojim dodatnim novčanim uplatama u društvo. Njima se ne povećava temeljni kapital, već ta sredstva ulaze u rezerve kapitala koje društvu služe za pokriće gubitka i nominalno povećanje temeljnog kapitala. O tome više u Bogdanović, O., Dodatne činidbe u društvu s ograničenom odgovornošću, Pravnik, vol. 46, br. 93., 2013., str. 150.-153.

8 Barbić, J., Pravo društava, Knjiga druga: društva kapitala, Svezak I.: dioničko društvo, Organizator, Zagreb, 2010., str. 41.-47., Ivkošić, M., Kapitalno orijentirani sustav zaštite vjerovnika društva s ograničenom odgovornošću, Zbornik Pravnog fakulteta u Zagrebu, vol. 70, br. 1., 2020., str. 112.-115.

9 Neto imovinu društva čini ukupna aktiva umanjenja za obveze, rezervacije i odgođena plaćanja troškova i prihoda budućeg razdoblja te rezerve kapitala i rezerve za vlastite poslovne udjele, ako ih društvo mora imati.

10 Npr. isplata dividende iz dobiti koja proizlazi iz računa dobiti i gubitka tekuće poslovne godine i zadržane dobiti, uz prethodno pokriće gubitka društva, stjecanje vlastitih poslovnih udjela i povlačenje poslovnih udjela za koje su ulozi u cijelosti uplaćeni, oslobađanje od obveze na dodatnu novčanu uplatu, ako je poslovni udio u cijelosti uplaćen, povrat dodatnih novčanih uplata članovima, ako su svi poslovni udjeli uplaćeni u cijelosti, isplata otpremnine članu društva u slučaju njegova istupanja ili isključenja iz društva, oblikovanje rezervi za vlastite poslovne udjele i korištenje rezervi kapitala za propisane svrhe. 
Dr. sc. Dionis Jurić: Uplata novčanog uloga za preuzete poslovne udjele i pravne posljedice neuplate u... Zbornik radova Pravnog fakulteta u Splitu, god. 58, 4/2021, str. 1165-1184

Članovi društva s ograničenom odgovornošću ne odgovaraju za obveze društva svojom osobnom imovinom (načelo neodgovornosti za obveze društva). ${ }^{11}$ Ona je odijeljena od imovine društva. Član samo snosi ograničeni rizik za uspješnost poslovanja društva s onime što je uložio u društvo ili što je u njega obvezan uložiti. Iznimka od toga će biti ako zloupotrebljava svoju neodgovornost za obveze društva (proboj pravne osobnosti). To je temeljno obilježje društava kapitala.

\section{OBVEZA UPLATE NOVČANOG ULOGA ZA PREUZETE POSLOVNE UDJELE}

Temeljni kapital društva s ograničenom odgovornošću mora biti izražen u kunama (čl. 389. st. 1. ZTD). Iznos temeljnog kapitala određuje se društvenim ugovorom, odnosno izjavom o osnivanju svakoga pojedinog društva (čl. 388. t. 3. ZTD). ZTD određuje da je najniži iznos temeljnog kapitala 20.000,00 kuna (čl. 389. st. 2. ZTD). ${ }^{12}$ Svaki viši iznos temeljnog kapitala određen društvenim ugovorom mora biti izražen cijelim brojem koji je višekratnik broja sto. Posebni propisi mogu određivati i viši iznos najnižega temeljnog kapitala društva s ograničenom odgovornošću, s obzirom na njegov predmet poslovanja (npr. pružatelji financijskih usluga). Sud kojemu se podnosi prijava za upis osnivanja u sudski registar mora odbiti upis društva čiji je temeljni kapital manji od najniže propisanog (čl. 395. st. 3. ZTD). Nominalni iznos poslovnog udjela ne može biti manji od 200,00 kuna. Nominalni iznos poslovnog udjela mora biti izražen cijelim brojem koji je višekratnik broja sto. Zbroj nominalnih iznosa svih poslovnih udjela mora odgovarati iznosu temeljnog kapitala društva (čl. 390. st. 1. ZTD). Pri osnivanju društva svaki član može preuzeti više poslovnih udjela, a njihov nominalni iznos ne mora biti jednak (čl. 385. st. 1 . ZTD).

Za svaki preuzeti poslovni udio član mora u društvo unijeti ulog. Način uplate, odnosno unosa uloga uređen je čl. 390. ZTD-a koji određuje najniži iznos uplata uloga u novcu, odnosno način unosa stvari i prava u društvo prije upisa osnivanja. ${ }^{13}$

11 Od tog načela postoje i dvije iznimke propisane zakonom, pri čemu je odgovornost članova društva vremenski ograničena. Glavno društvo odgovara vjerovnicima priključenog društva kao solidarni dužnik za obveze toga društva nastale prije i nakon priključenja (čl. 506. st. 1. ZTD). Odgovornost traje od upisa priključenja do objave upisa prestanka priključenja. Ta je odgovornost glavnog društva propisana zbog širokih ovlasti koje ono stječe prema priključenom društvu. Ako je društvo s ograničenom odgovornošću prestalo po skraćenom postupku, bez likvidacije, nakon njegovog brisanja iz sudskog registra za eventualne obveze društva odgovaraju njegovi bivši članovi solidarno cijelom svojom imovinom (čl. 472.e ZTD). Vjerovnici mogu tražbine koje su imali prema društvu ostvariti prema njegovim bivšim članovima u roku od dvije godine od dana objave brisanja društva iz sudskog registra. Član društva koji podmiri tražbinu ima pravo regresa prema ostalim članovima društva. Time se sankcioniraju eventualni propusti pri provedbi skraćenog postupka za prestanak društva. Vidi u Barbić, op. cit. u bilj. 8, str. 16.-17.

12 Ako se osniva jednostavno društvo s ograničenom odgovornošću najniži iznos temeljnog kapitala društva je 10,00 kuna, a najniži nominalni iznos poslovnog udjela 1,00 kuna. Temeljni kapital i poslovni udjeli u društvu moraju glasiti na pune iznose kuna (čl. 390.a st. 3. ZTD). Iznos temeljnog kapitala društva određuje se obrascem zapisnika i može se kretati u rasponu od 10,00 kuna do najviše 19.999,00 kuna.

13 Te se odredbe primjenjuju i pri naknadnom povećanju temeljnog kapitala društva. 
Dr. sc. Dionis Jurić: Uplata novčanog uloga za preuzete poslovne udjele i pravne posljedice neuplate u... Zbornik radova Pravnog fakulteta u Splitu, god. 58, 4/2021, str. 1165-1184

Ostatak novčanog uloga može se uplatiti i nakon toga. ${ }^{14}$ Opseg i dospijeće obveze uplate novčanih uloga za preuzete poslovne udjele može se odrediti društvenim ugovorom ili odlukom skupštine, odnosno članova društva (čl. 398. st. 2. ZTD). ${ }^{15}$ Visina uloga određuje se prema nominalnom iznosu poslovnog udjela utvrđenom $\mathrm{u}$ društvenom ugovoru pri osnivanju (čl. 398. st. 1. ZTD). ${ }^{16}$

Prije upisa osnivanja društva u sudski registar svaki član društva mora uplatiti najmanje četvrtinu uloga za preuzeti poslovni udio kojega uplaćuje u novcu. Pritom ukupni iznos svih uplata u novcu ne može biti manji od jedne četvrtine temeljnog kapitala, osim ako zakonom nije drukčije propisano (čl. 390. st. 2. ZTD). Ta se dva uvjeta moraju kumulativno ispuniti. Ako je temeljni kapital društva 20.000,00 kuna tada ukupni iznos svih uplata u novcu mora iznositi 5.000,00 kuna. Tom se izmjenom ZTD-a iz 2019. godine olakšava uplata novčanih uloga, budući da više nije potrebno da ukupni iznos svih uplata u novcu iznosi najmanje 10.000,00 kuna. Taj je iznos činio polovicu najnižeg iznosa temeljnog kapitala potrebnog za osnivanje društva s ograničenom odgovornošću. ${ }^{17}$

14 U knjigu se poslovnih udjela upisuju nominalni iznosi poslovnih udjela koje je preuzeo član društva i što je na temelju toga uplatio društvu (čl. 410. st. 1. ZTD).

15 Ako se ulog u društvo unosi u stvarima i pravima, on se mora u cijelosti unijeti prije upisa osnivanja društva u sudski registar. Ako je vrijednost tih stvari i prava u vrijeme podnošenja prijave za upis osnivanja u sudski registar manja od vrijednosti uloga koji se time ulaže, razlika do visine tako izraženog uloga mora se uplatiti u novcu (čl. 390. st. 3. ZTD). Tada se mora sastaviti i izvješće o osnivanju, obaviti revizija osnivanja ili procjena vrijednosti tih uloga (osnivanje društva ulaganjem stvari ili prava bez revizije osnivanja)(čl. 390. st. 4. ZTD).

16 Pri povećanju temeljnog kapitala društva, ona se određuje nominalnim iznosom udjela navedenom u izjavi o njegovu preuzimanju.

17 U slovenskom pravu čl. 475. st. 4. Zakona o trgovačkim društvima (slov. Zakon o gospodarskih družbah) određuje da prije upisa društva u sudski registar svaki član društva mora uplatiti najmanje četvrtinu temeljnog uloga u novcu, pri čemu ukupni iznos svih uplaćenih uloga mora iznositi 7.500,00 eura. Najniži iznos temeljnog kapitala društva s ograničenom odgovornošću je 7.500,00 eura, a najniži iznos temeljnog uloga 50,00 eura. Vidi u Ivanjko; Kocbek; Prelič, op. cit. u bilj. 5, str. 881.-882. U njemačkom pravu § 7 st. 2. Zakona o društvima s ograničenom odgovornošću (njem. GmbH Gesetz) određuje da prije upisa društva u trgovački registar svaki član društva mora uplatiti najmanje četvrtinu novčanog uloga za preuzeti poslovni udio. Pritom ukupni iznos svih uplata u novcu ne može biti manji od polovice najnižeg iznosa temeljnog kapitala društva (12.500,00 eura). Najniži iznos temeljnog kapitala društva je 25.000,00 eura, a najniži nominalni iznos poslovnog udjela je 1,00 euro. U austrijskom pravu § 10 st. 1 . Zakona o društvima s ograničenom odgovornošću određuje da prije upisa društva u trgovački registar svaki član društva mora uplatiti najmanje četvrtinu novčanog uloga, ali ne manje od 70,00 eura. Pritom ukupni iznos svih uplata u novcu ne može biti manji od 17.500,00 eura. Najniži iznos temeljnog kapitala društva je 35.000,00 eura, a najniži iznos temeljnog uloga je 70,00 eura. U § 10b austrijskog Zakona predviđeno je da osnivači društva mogu u društvenom ugovoru predvidjeti primjenu osnivačke privilegije (njem. Gründungsprivilegierung) te odrediti iznose privilegiranih novčanih uloga svakog osnivača društva. To se upisuje u trgovački registar. Osnivačka privilegija traje najdulje 10 godina od dana upisa osnivanja društva u trgovački registar. Tada članovi društva moraju unijeti privilegirane novčane uloge (njem. gründungsprivilegierten Stammeinlagen) u društvo. Oni moraju unijeti novčane uloge čija ukupna vrijednost ne smije biti manja od 10.000,00 eura, a prije upisa društva u registar moraju uplatiti najmanje 5.000,00 eura. Pri tom osnivanju nisu dopušteni ulozi u stvarima ili pravima. I tada je najniži iznos temeljnog kapitala društva 35.000,00 eura. Sve dok traje osnivačka privilegija vjerovnici se mogu namiriti od društva samo do ukupnog iznosa privilegiranih uloga. To vrijedi i ako je nad društvom otvoren stečaj. Članovi društva mogu u svako doba ukinuti osnivačku privilegiju izmjenom društvenog ugovora te uplatiti novčane uloge do iznosa od 17.500,00 eura. Osnivačka privilegija prestaje nakon proteka 10 godina od upisa društva u trgovački registar, kada uprava mora zatražiti od članova društva uplatu novčanih uloga do iznosa od 17.500,00 eura i podnijeti prijavu za upis prestanka privilegije u registar. Vidi u Schmidt, S., Austria's Limited Liability Companies: „Less Light“, http://roadmap2015.schoenherr.eu/austrias-limited-liability-companies-less-light/, 7. kolovoza 2020. 
Izmjenom ZTD-a iz 2009. godine određen je i krajnji rok za uplatu preostalog novčanog uloga za preuzete poslovne udjele. Preostali se novčani ulog mora u cijelosti uplatiti u roku od jedne godine od dana upisa društva u sudski registar. Time se ograničava sloboda članova društva odrediti društvenim ugovorom ili njihovom odlukom po slobodnoj poduzetničkoj ocjeni dospijeće uplate preostalog novčanog uloga. ${ }^{18}$ Dodatno se propisuje da osnivač koji nije uplatio ulog za preuzeti poslovni udio odgovara za obveze društva osobno i solidarno sa svim drugim osnivačima koji nisu uplatili uloge za preuzete poslovne udjele do visine iznosa neuplaćenih uloga za sve poslovne udjele u društvu. ${ }^{19}$ Time se odstupa od načela da članovi društava kapitala ne odgovaraju osobnom imovinom za obveze društva. Pritom nije potrebno dokazivati zloupotrebu članova društva, već je dovoljno da nisu uplatili novčane uloge u cijelosti. ${ }^{20}$ Također se ne vodi računa o tome koliko je koji član društva uplatio za svoj poslovni udio, što može dovesti do kasnijih sporova pri ostvarivanju prava regresa. ${ }^{21}$

Od tog općeg režima uplate novčanih uloga pri osnivanju društva s ograničenom odgovornošću, posebnim se propisima određuje da u društvima koja su pružatelji financijskih usluga članovi moraju novčane uloge za sve preuzete poslovne udjele uplatiti u cijelosti prije upisa osnivanja u sudski registar te da ulozi mogu biti samo u novcu. ${ }^{22}$ Isto vrijedi i za osnivanje jednostavnog društva s ograničenom odgovornošću (čl. 390.a st. 4. ZTD) ${ }^{23}$

Novčani se ulozi moraju uplatiti tako da njima društvo može slobodno raspolagati nakon upisa njegovog osnivanja u sudski registar (čl. 390. st. 5. ZTD). Oni se uplaćuju u kunama na račun društva kod domaće kreditne institucije. Ta institucija izdaje potvrdu o tome da će društvo moći slobodno raspolagati s uplaćenim iznosom nakon njegovog upisa u sudski registar (čl. 390. st. 6. ZTD). Ako društvo osniva

18 Oni bi to mogli odrediti i prije isteka tog roka, ali ako to ne učine, po isteku jedne godine od dana upisa društva u sudski registar nastaje obveza članova društva koji nisu uplatili novčane uloge platiti zatezne kamate te nadoknaditi štetu društvu, a može se provesti i postupak kaduciranja. Te će mjere poduzimati uprava društva samostalno.

19 Sličan položaj imaju komanditori koji nisu uplatili u cijelosti uloge na koje su se obvezali društvenim ugovorom, koji tada vjerovnicima društva odgovaraju neposredno i solidarno s komplementarima, ali samo do visine ugovorenih uloga umanjenih za uplaćeni dio (čl. 143. st. 2. ZTD). Budući da u društvima osoba nema temeljnog kapitala, zaštita se vjerovnicima pruža osobnom i solidarnom odgovornošću članova društva za njegove obveze. Pritom je ta odgovornost neograničena za članove javnog trgovačkog društva, komplementare u komanditnom društvu te članove gospodarskog interesnog udruženja. Vidi u Ivkošić, M., Društvo s ograničenom odgovornošću u svjetlu novele Zakona o trgovačkim društvima iz 2019., Zbornik radova Pravnog fakulteta u Splitu. god. 57, br. 2., 2020., str. 555.

20 Osobnu odgovornost za obveze društva osnivači mogu izbjeći uplatom novčanih uloga u cijelosti prije upisa društva u sudski registar.

${ }^{21}$ Loc. cit. Član koji je platio tražbinu društva ima pravo regresa prema društvu, a ako mu društvo to ne plati, ima pravo regresa prema članovima društva koji nisu uplatili uloge u cijelosti. Na svakog člana otpada onoliko koliko nije uplatio ulog za preuzeti poslovni udio.

22 Npr. društva za upravljanje investicijskim i mirovinskim fondovima, leasing i faktoring društva, investicijska društva i sl.

23 Jednostavna društva s ograničenom odgovornošću imaju obvezu oblikovati zakonske rezerve, čime se štiti društvo i njegovi vjerovnici. Ako se osniva društvo s ograničenom odgovornošću na daljinu, to je moguće samo ako se ulozi za preuzete poslovne udjele uplaćuju samo u novcu, pri čemu se primjenjuje opće režim uplate novčanih uloga. 
samo jedan osnivač, on mora prije podnošenja prijave za upis osnivanja društva u sudski registar svoj novčani ulog uplatiti u cijelosti ili dati primjereno osiguranje društvu da će dio novčanog uloga koji do tada nije uplatio biti uredno plaćen (čl. 394. st. 2. ZTD) ${ }^{24}$

Obveza je članova društva uplatiti uloge u novcu razmjerno njihovim preuzetim poslovnim udjelima (čl. 398. st. 2. ZTD). Za određivanje razmjernosti mjerodavni su nominalni iznosi poslovnih udjela, a ako se neki uplaćuju u stvarima ili pravima i u novcu, mjerodavni su samo iznosi plaćanja u novcu. Time se osigurava primjena načela unosa temeljnog kapitala te načela jednakog položaja članova u društvu. Ovo se pravilo primjenjuje pri plaćanju nominalnog iznosa poslovnog udjela, plaćanju agia (preuzimanje poslovnih udjela super pari) i plaćanju s naslova odgovornosti za uplate drugih članova društva. ${ }^{25}$ Ono se primjenjuje na početno plaćanje, na plaćanje ostatka nakon prve uplate i na plaćanje pri povećanju temeljnog kapitala društva. ${ }^{26}$ Društvenim se ugovorom ili odlukom skupštine, odnosno članova društva može odrediti i drukčije. ${ }^{27}$

Član mora uplatiti novčani ulog društvu u roku koji je određen društvenim ugovorom i odredbom čl. 390. ZTD-a. Ako društveni ugovor ne sadrži odredbe o dospijeću obveze uplate uloga ili se članovi pri njegovom sklapanju nisu kod javnog bilježnika obvezali na plaćanje uloga u određenom roku, obveza dospijeva sa zahtjevom za uplatu koji postavi uprava, ali joj je za to potrebna i odluka skupštine, odnosno članova društva. ${ }^{28}$ Skupština donosi odluku prema slobodnoj poduzetničkoj ocjeni članova društva, pri čemu pravo glasa ima i član društva o čijoj se obvezi radi. Odluka se donosi običnom većinom glasova, osim ako društvenim ugovorom nije određeno drukčije. Uprava upućuje poziv članovima društva za uplatu neuplaćenog dijela novčanog uloga sukladno s društvenim ugovorom ili odlukom skupštine, odnosno članova društvaa. ${ }^{29}$ Ako je društvo u stečaju ili se provodi likvidacija, stečajni upravitelj i likvidatori moraju zatražiti od svih članova društva uplatu poslovnih udjela. Tada se prednost daje interesima vjerovnika, a uplatama novčanih uloga osigurava se oblikovanje stečajne, odnosno likvidacijske mase iz koje se namiruju tražbine vjerovnika. Tada neće biti važne odredbe društvenog ugovora ili drukčije odluke skupštine društva o uplati novčanih uloga. ${ }^{30}$

24 Član društva može dati svako primjereno osiguranje koje je moguće po pravilima građanskog prava. Kada uplati novčani ulog u cijelosti, član ima pravo tražiti povrat osiguranja. Registarski sud ispituje primjerenost osiguranja pri upisu društva u sudski registar. Vidi u Barbić, J., Pravo društava, Knjiga druga: društva kapitala, Svezak II.: društvo s ograničenom odgovornošću, društvo za uzajamno osiguranje, kreditna unija, Organizator, Zagreb, 2010., str. 58.

25 Ibid., str. 194

26 Pravilo se odnosi na opseg uplate i na postupanje pri plaćanju (način, mjesto i vrijeme plaćanja). Ono vrijedi samo unutar društva, a ne i prema trećim osobama. Vidi u ibid., str. 195. kasnije.

27 Tako se može odrediti da neki član odmah uplati u cijelosti novčani ulog, a neki drugi da dio uplati

${ }_{28}$ Tu odluku članovi društva mogu donijeti na skupštini, ali i izvan nje, ako je donesu jednoglasno te u pisanom obliku.

29 Ibid., str. 196.

30 Ibid., str. 195.-196. 
Ako dođe do prijenosa poslovnog udjela, za obvezu uplate uloga koja postoji kada je društvu podnesena prijava za upis prijenosa udjela u knjigu poslovnih udjela, solidarno odgovaraju stjecatelj poslovnog udjela i njegov pravni prednik (čl. 415. st. 2. ZTD). Zahtjev za ispunjavanje prema pravnom predniku zastarijeva u roku od pet godina od podnošenja prijave za upis prijenosa poslovnog udjela u knjigu poslovnih udjela (čl. 415. st. 3. ZTD). ${ }^{31}$

Društvo ne može pojedinim članovima odgoditi, olakšati niti ih osloboditi od obveze uplate uloga za preuzete poslovne udjele, a ne može ni svoje tražbine s naslova uplate uloga prebiti s tražbinom protiv društva (čl. 398. st. 3. ZTD). Smanjenjem se temeljnog kapitala članovi društva mogu osloboditi obveze uplate uloga za preuzete poslovne udjele najviše do iznosa za koji je smanjen taj kapital (čl. 398. st. 6. ZTD). Tada vjerovnici društva mogu tražiti da im se podmire dospjele tražbine, odnosno da im se da osiguranje za nedospjele tražbine u roku od 3 mjeseca od dana objave namjere društva smanjiti temeljni kapital (čl. 463. st. 2. ZTD). ${ }^{32}$ Provedeno se smanjenje temeljnog kapitala može upisati u sudski registar tek po proteku toga rok, a upis ima konstitutivni učinak (čl. 464. st. 1. ZTD). Nakon toga djeluje i oslobođenje od obveze uplate preostalih neuplaćenih uloga za preuzete poslovne udjele (čl. 465. st. 2. ZTD). ${ }^{33}$

Članovi društva ne mogu tražiti da im društvo vrati ono što su uplatili kao uloge za preuzete poslovne udjele dok ono traje. Članovima se ne smije isplatiti kamata na uplaćeni ulog niti se može ugovoriti takva obveza društva (čl. 406. st. 1. ZTD). Članovi društva kojima društvo nešto isplati protivno odredbama ZTD-a, društvenog ugovora ili odlukama društva moraju te primljene isplate vratiti društvu (čl. 407. st. 2. ZTD). Zahtjev za povrat nedopuštenog primanja prema članu ima društvo, a može ga ostvariti i tužbom koju može podići uprava, ali i svaki drugi član društva u svoje ime, a za račun društva (lat. actio pro socio). Vjerovnici društva to ne mogu činiti. ${ }^{34}$ Obveza povrata postoji i ako član naknadno prenese svoj poslovni udio. Zahtjevi društva zastarijevaju u roku od pet godina od dana kada je član društva primio nedopušteno primanje, osim ako društvo ne dokaže da je on znao za nedopuštenost isplate (čl. 407. st. 6. ZTD). ${ }^{35}$

31 To vrijedi za dospjele i nedospjele obveze, neovisno o tome je li stjecatelj znao ili morao znati za njih. Vidi u ibid., str. 178.

32 Namjera smanjenja temeljnog kapitala društva mora se upisati u sudski registar te se mora objaviti na mrežnoj stranici sudskog registra i u glasilu društva, ako ga ono ima (čl. 463. st. 1. i 2. ZTD). Time se vjerovnici obavještavaju o smanjenju temeljnog kapitala te im se omogućava postaviti zahtjeve za namirenje dospjelih tražbina, odnosno davanje osiguranja za nedospjele tražbine. Poznatim se vjerovnicima ta obavijest dostavlja. Vidi u ibid., str. 516.-518.

33 Ibid., str. 518.-519.

34 Zahtjev za povrat nedopuštenog primanja društvo može ustupiti vjerovniku ili on može tražbinu društva prema članu zahvatiti u ovrsi koju vodi protiv društva. Vidi u Širola, N., Odgovornost članova društva s ograničenom odgovornošću za nedopušten zahvat u imovinu društva, Zbornik Pravnog fakulteta u Zagrebu, vol. 61, br. 5., 2011., str. 1709.

35 Ako se nedopušteno primanje ne može naplatiti od člana društva ni od članova uprave, ostali članovi odgovaraju društvu za takvu naplatu u omjeru svojih poslovnih udjela, ako su ta sredstva potrebna za namirenje vjerovnika (čl. 407. st. 4. ZTD). Vidi u Barbić, op. cit. u bilj. 24, str. 296.-299., Ivkošić, op. cit. u bilj. 8, str. 122.-128., Širola, op. cit. u bilj. 34, str. 1704.-1706. 


\title{
4. PRAVNE POSLJEDICE NEUPLATE NOVČANOG ULOGA ZA PREUZETE POSLOVNE UDJELE
}

\begin{abstract}
ZTD propisuje i pravne posljedice u slučaju zakašnjenja člana društva s uplatom novčanih uloga za preuzete poslovne udjele. To su: a) obveza plaćanja zateznih kamata (čl. 399. ZTD), b) isključenje člana društva koji je u zakašnjenju s uplatom uloga (čl. 400. ZTD), c) odgovornost prednika isključenog člana za obvezu uplate uloga (čl. 401. ZTD), d) prodaja poslovnog udjela isključenog člana (čl. 402. ZTD) te e) odgovornost ostalih članova društva za uplatu uloga isključenog člana (čl. 403. ZTD). ${ }^{36}$ Te mjere prema članu poduzima uprava društva. ${ }^{37}$ Odredbe čl. 400.-404. ZTD-a su prisilne naravi te se članovi društva ne mogu osloboditi pravnih posljedica koje proizlaze iz primjene tih odredbi (čl. 405. ZTD). Time se društvo osigurava da će biti uplaćeni novčani ulozi za preuzete poslovne udjele te da će imati temeljni kapital u iznosu koji je određen društvenim ugovorom.
\end{abstract}

\subsection{Obveza plaćanja zateznih kamata}

Član društva koji na vrijeme ne uplati ulog za preuzeti poslovni udio mora društvu od dospijeća obveze do njezinog ispunjenja platiti zatezne kamate po stopi određenoj zakonom. Društvenim se ugovorom ili odlukom organa društva, ${ }^{38}$ koja je donesena prije preuzimanja obveze članova društva uplatiti uloge, može odrediti i viša stopa tih kamata (čl. 399. ZTD). ${ }^{39}$ Obveza plaćanja zateznih kamata postoji samo u odnosu na uplatu poslovnog udjela u novcu. ${ }^{40}$ Ako se poslovni udio dijelom uplaćuje u novcu, a dijelom unosom stvari i prava, zatezna se kamata plaća samo za zakašnjenje s novčanom uplatom. ZTD ne isključuje odgovornost za štetu koja je nastala društvu zbog zakašnjenja člana društva s uplatom poslovnog udjela. Društvo može tražiti naknadu štete od člana društva prema općim pravilima o odgovornosti za štetu, pri čemu mora postojati i njegova krivnja. Iznos uplaćenih zateznih kamata se unosi u rezerve kapitala (čl. 406.a st. 1. t. 1. ZTD). Zahtjevi za uplatu uloga za preuzete poslovne udjele zastarijevaju u roku od pet godina od njihova dospijeća. ${ }^{41}$

36 Odredbe o obvezi plaćanja zateznih kamata, isključenju člana iz društva i odgovornosti njegovih prednika primjenjivat će se i u slučaju neispunjenja obveze na dodatnu novčanu uplatu koja je ograničena određenim iznosom, odnosno koja nije ograničena određenim iznosom, ako dodatna uplata ne prelazi iznos određen društvenim ugovorom (čl. 391. st. 3. ZTD). Društvenim se ugovorom može odrediti i drukčije. Vidi u Barbić, op. cit. u bilj 24, str. 224.-225., Bogdanović, op. cit. u bilj. 7, str. 163.-164.

37 Iste pravne posljedice predviđa i njemačko (§ 20-24 GmbH Gesetz), austrijsko ( $\$ 65-70 \mathrm{GmbH}$ Gesetz) te slovensko pravo (čl. 485.-489. Zakona o gospodarskih družbah).

38 To će biti onaj organ društva koji je određen društvenim ugovorom, a ako o tome nema odredbi u njemu, odluku o tome donosi uprava. Vidi u Barbić, op. cit. u bilj. 24, str. 200.

39 Ne može se odrediti niža stopa zateznih kamata od one koja je određena zakonom te ona mora biti jednaka za sve članove društva. Ako bi se tako odredilo odlukom skupštine društva, ona bi bila pobojna.

40 Zatezne se kamate plaćaju u slučaju zakašnjenja s uplatom novčanog uloga koja je određena društvenim ugovorom ili zakonom određenog dijela novčanog uloga prije upisa osnivanja društva $u$ sudski registar te uplatu preostalog novčanog uloga nakon upisa društva u sudski registar.

41 Ibid., str. 199.-201. 


\subsection{Isključenje člana društva koji je u zakašnjenju s uplatom uloga (kaduciranje)}

Društvo može provesti i postupak isključenja člana društva zbog nepravodobne uplate novčanog uloga za preuzete poslovne udjele (kaduciranja) (čl. 400. ZTD). To je najteža sankcija za neuplatu, odnosno zakašnjenje s uplatom novčanog uloga člana društva. Njime se osigurava uplata temeljnog kapitala društva, čime se štite njegovi vjerovnici. Kaduciranje nije obvezatna mjera koju poduzima društvo, ali se ono može unaprijed predvidjeti društvenim ugovorom. Pritom se mora poštovati načelo jednakog položaja članova u društvu. Odredbe ZTD-a o kaduciranju člana društva primjenjuju se samo ako se ulog uplaćuje u novcu. One su prisilne naravi te se ne mogu izmijeniti društvenim ugovorom.

Društvo može člana društva koji je u zakašnjenju s uplatom uloga pozvati pisanim putem da ispuni svoju obvezu u naknadnom roku koji mu se za to mora dati. Pritom ga mora upozoriti da će, ako ne uplati ulog, biti isključen iz društva. Poziv se mora poslati preporučenim pismom, a naknadni rok ne može biti kraći od mjesec dana. Ako se poziv upućuje većem broju članova, naknadni rok za sve mora biti jednak. Nije dopušteno od toga izuzeti pojedine članove društva koji kasne s uplatom uloga. Kaduciranje se ne može primijeniti zbog neplaćanja zateznih kamata, ugovorne kazne, neuplate onoga što nije uplatio neki drugi član društva (čl. 385. st. 3. i čl. 403. ZTD) ili neispunjenja dodatnih obveza. ${ }^{42}$

Poziv u ime društva upućuje uprava, ali se društvenim ugovorom može na to ovlastiti i neki drugi organ društva. U likvidaciji poziv upućuju likvidatori, a ako je nad društvom otvoren stečajni postupak, to čini stečajni upravitelj. Društvo može protiv člana ustati s tužbom kojom traži uplatu uloga, što ne otklanja mogućnost da ga se isključi iz društva. Taj se sudski postupak može voditi usporedo s postupkom isključenja člana iz društva zbog neuplate uloga, dok se jedan od njih ne okonča (čl. 400. st. 1. ZTD). ${ }^{43}$

Ako član društva ne uplati poslovni udio ni u naknadnom roku, uprava oglašava da je on u korist društva izgubio svoj poslovni udio i djelomičnu uplatu uloga. Tu izjavu uprava mora priopćiti članu preporučenim pismom (čl. 400. st. 2. ZTD). Društvo se ne mora koristiti tim svojim pravom. Uprava po slobodnoj ocjeni odlučuje hoće li isključiti člana, a to je ne sprječava da i dalje ustraje pri tužbenom zahtjevu kojim se traži uplata uloga ili tu tužbu može podići tek tada. Priopćenjem te izjave član gubi ubuduće članstvo u društvu, kao i dio uplaćenog uloga za predmetni poslovni udio. Pritom isključeni član i dalje odgovara za uplatu neuplaćenog dijela

42 To se može učiniti ako se poslovni udio dijelom uplaćuje u novcu, a dijelom unosom stvari i prava, pa se ne uplati onaj dio koji se mora uplatiti u novcu, kada se zbog smetnji u ispunjenju obveze unosa stvari i prava obveza člana pretvara u obvezu uplate novca te kada se mora uplatiti iznos razlike vrijednosti uloga u stvarima i u pravima koja je u vrijeme podnošenja prijave za upis društva u sudski registar manja od vrijednosti poslovnog udjela koji se time uplaćuje. Vidi u ibid., str. 202.-203.

43 Ako društvo uspije s naplatom uloga u sudskom postupku, član ostaje u društvu. Vidi u ibid., str. 202. i 204.-205. 
uloga, i to prije drugih članova društva ${ }^{44}$ Time se ne isključuje njegova odgovornost za štetu počinjenu društvu zbog neuplate uloga (čl. 400. st. 3. ZTD). ${ }^{45}$

Poslovni udio isključenog člana pripada društvu koje ga drži kao povjerenik za onoga koji će ga kasnije steći (pravni prednik isključenog člana ili kupac udjela) uz uplatu uloga za udio. Prava i obveze iz udjela miruju dok on pripada društvu, a dividenda koja bi za to vrijeme otpala na njega pripada onome tko će ga poslije steći od društva. Isključenom članu ostaju prava i obveze koje su nastale prije njegovog isključenja iz društva. ${ }^{46}$

\subsection{Odgovornost prednika isključenog člana za uplatu uloga}

$\mathrm{Za}$ ispunjenje obveze uplate novčanog uloga isključenog člana odgovaraju društvu i posljednji te svi njegovi raniji pravni prednici koji u odnosu na društvo vrijede kao imatelji poslovnih udjela (čl. 401. st. 1. ZTD) ${ }^{47}$ Imateljima poslovnih udjela smatraju se one osobe za koje je bila podnesena prijava za upis u knjigu poslovnih udjela, a koja je ispunjavala sve uvjete za upis (čl. 401. st. 2. ZTD) ${ }^{48}$ Odgovornost pravnih prednika isključenog člana temelji se na tome da su oni prenijeli svoje poslovne udjele za koje novčani ulozi nisu bili uplaćeni u cijelosti na isključenog člana.$^{49}$ Odgovornost pravnog prednika ograničava se na obvezu uplate uloga $a^{50}$ i na vrijeme od pet godina od dana kada je njegov pravni sljednik prema društvu vrijedio kao imatelj poslovnog udjela (čl. 401. st. 3. ZTD). Što se tiče redoslijeda odgovornosti pravnih prednika, naplata se uloga može tražiti od ranijeg prednika samo ako obvezu ne podmiri njegov sljednik (neposredni prednik isključenog člana). Smatra se da sljednik nije podmirio obvezu ako to ne učini u roku od mjesec dana od kada mu se za to uputi poziv preporučenim pismom i o tome na isti način obavijesti njegovog prednika (čl. 401. st. 2. ZTD) ${ }^{51}$ Poziv za uplatu uloga sljedniku i obavijest njegovom predniku o upućivanju poziva šalje uprava.

44 Odgovornost isključenog člana je primarna, a odgovornost ostalih članova društva za uplatu njegovog uloga je supsidijarna.

45 Ibid., str. 205.

46 Npr. pripada mu pravo na isplatu dividende za koju je u društvu odluka donesena prije njegovog isključenja, mora ispuniti sve dodatne činidbe društvu koje su dospjele prije njegovog isključenja, nastavlja se njegova odgovornost nastala prije isključenja za uplatu poslovnih udjela drugih članova koji to nisu učinili. Prava trećih osoba na udjelu prestaju po sili zakona, a ovrhu na udjelu treba obustaviti. Vidi u ibid., str. 205.-206.

47 Odredba čl. 401. ne isključuje primjenu odredbe čl. 415. st. 2. ZTD-a o solidarnoj odgovornosti stjecatelja poslovnog udjela i njegovog pravnog prednika za obvezu uplate uloga koja postoji kada je društvu podnesena prijava za upis prijenosa udjela u knjigu poslovnih udjela, ako je poslovni udio prenesen.

48 To ne vrijedi za sveopće pravne sljednike.

49 Radi se o zakonskom jamstvu prednika za obvezu isključenog člana. Vidi u Barbić, op. cit. u bilj. 24, str. 207.-208., Ivanjko; Kocbek; Prelič, op. cit. u bilj. 5, str. 897.

50 On ne odgovara za plaćanje zateznih kamata, već je to i dalje obveza isključenog člana. U austrijskom pravu $\S 67$ st. 2. Zakona o društvima s ograničenom odgovornošću propisuje odgovornost pravnih prednika isključenog člana i za uplatu zateznih kamata.

51 Djelomična uplata pravnih sljednika smanjuje zahtjev društva prema pravnom predniku. 
Dr. sc. Dionis Jurić: Uplata novčanog uloga za preuzete poslovne udjele i pravne posljedice neuplate u... Zbornik radova Pravnog fakulteta u Splitu, god. 58, 4/2021, str. 1165-1184

Uplatom preostalog dijela uloga pravni prednik stječe poslovni udio isključenog člana u društvu, ako ga do tada društvo već nije prodalo (čl. 401. st. 4. ZTD).$^{52}$

\subsection{Prodaja poslovnog udjela isključenog člana}

Ako se nije mogla postići uplata cijelog poslovnog udjela od pravnih prednika isključenog člana ${ }^{53}$ ili takvih prednika nema, društvo mora njegov poslovni udio prodati na javnoj dražbi (čl. 402. st. 1. ZTD). Pritom uprava ocjenjuje najpovoljnije vrijeme za prodaju poslovnog udjela, uzimajući u obzir prilike na tržištu. Javnu dražbu provode osobe ovlaštene za održavanje javnih dražbi ili sud (čl. 402. st. 3. ZTD).$^{54} \mathrm{Na}$ kupca se po isplati cijene prenosi poslovni udio te ga društvo upisuje u knjigu poslovnih udjela. ${ }^{55}$ Ako kupovnina ne pokriva cijeli iznos potrebne uplate udjela, za uplatu razlike odgovaraju isključeni član i drugi članovi društva. Ako je kupovnina viša od onoga što treba uplatiti društvu, višak se po odbitku troškova prodaje i zateznih kamata, nakon uplate uloga društvu, isplaćuje isključenom članu (čl. 402. st. 4. ZTD). ${ }^{56}$

Za drukčiji način prodaje ili kada se poslovni udio prodaje nekom drugom članu društva po cijeni koja odgovara njegovoj stvarnoj vrijednosti, traži se suglasnost isključenog člana (čl. 402. st. 1. ZTD). Ta se suglasnost može dati i unaprijed u društvenom ugovoru pri osnivanju društva te njime predvidjeti pojedinosti takvih prodaja. ${ }^{57}$

Suglasnost isključenog člana nije potrebna za slobodnu prodaju poslovnog udjela koju uprava provodi u roku od mjesec dana nakon što su se stekli uvjeti za njegovu prodaju. Tada se on mora prodati najmanje za iznos njegove vrijednosti iskazan u izvješću o financijskom položaju društva (bilanci). Nakon proteka mjesec dana društvo može udio prodati samo na javnoj dražbi (čl. 402. st. 2. ZTD). ${ }^{58}$

Ako društvo ne uspije prodati poslovni udio, on pripada društvu, bez obzira što za njega ulog nije uplaćen u cijelosti. Na društvu je teret dokaza da se on nije mogao

52 Ako prednik ne stekne poslovni udio, on može od svojih sljednika zatražiti da mu nadoknade ono što je platio s kamatama i eventualnim troškovima (pravo regresa). Vidi u Barbić, op. cit. u bilj. 24, str. 210 .

53 Pozivi upućeni pravnim prednicima su bili neuspješni ili je njihova odgovornost prestala zbog zastare.

54 Na javnoj dražbi mogu sudjelovati članovi društva, isključeni član, njegovi pravni prednici, članovi organa društva u svoje ime ili u ime neke treće osobe te treće osobe. Vidi u ibid., str. 211.-212.

55 Tada ne vrijede eventualna ograničenja raspolaganja udjelom predviđena društvenim ugovorom te nije potrebno sklopiti ugovor o prijenosu poslovnog udjela u obliku javnobilježničke isprave.

56 Time se određuje redoslijed namirenja tražbina društva. To se primjenjuje i pri ostalim načinima prodaje poslovnog udjela. Vidi u ibid., str. 213.-214.

57 Tada se primjenjuju eventualna ograničenja raspolaganja poslovnim udjelom predviđena društvenim ugovorom te je potrebno sklopiti obveznopravni ugovor i ugovor o prijenosu poslovnog udjela u obliku javnobilježničke isprave. Vidi u ibid., str. 214.

58 Taj način prodaje predviđa i $§ 68$ st. 2. austrijskog Zakona o društvima s ograničenom odgovornošću. 
prodati. ${ }^{59}$ To ne isključuje odgovornost isključenog člana i drugih članova društva za neuplatu poslovnog udjela ni regres prema pravnim prednicima isključenog člana.

\subsection{Odgovornost ostalih članova za uplatu uloga isključenog člana}

Za obvezu uplate poslovnog udjela odgovaraju i ostali članovi društva. Njihova je odgovornost supsidijarna jer odgovaraju samo za ono što nije uplatio isključeni član, njegovi pravni prednici i za ono što društvo nije uspjelo dobiti prodajom poslovnog udjela. Njihova se odgovornost smanjuje za onoliko koliko društvo uspije naplatiti na ta tri načina. Društvo mora dokazati da su ispunjenje pretpostavke za zahtjev prema članovima društva. Ispunjenjem tih pretpostavki nastaje obveza ostalih članova društva uplatiti preostali neuplaćeni dio poslovnog udjela razmjerno njihovim udjelima u društvu. Razmjer se poslovnih udjela određuje odnosom njihovih nominalnih iznosa, a odgovornost članova nije solidarna (čl. 385. st. 3. i čl. 403. st. 1. ZTD). Obveznici su članovi društva koji su to bili u trenutku ispunjenja pretpostavki za postavljanje zahtjeva društva. ${ }^{60}$

Članovi društva koji uplate preostali dio poslovnog udjela ne stječu taj udio, ako ga društvo još ima, ${ }^{61}$ nego on prirasta njihovim udjelima. Ako društvu plate samo neki članovi, oni imaju pravo regresa prema ostalim članovima društva i isključenom članu. ${ }^{62}$ Ako poslovni udio nije prodan, članovi koji su podmirili obvezu uplate neuplaćenog poslovnog udjela stječu pravo sudjelovanja u dobiti društva i u ostatku likvidacijske, odnosno stečajne mase društva koji bi pripali tomu udjelu i to razmjerno iznosima koje su uplatili na ime zaostale uplate uloga koji se odnosi na taj udio. Ako se poslovni udio naknadno proda, iz postignutog utrška moraju se članovima društva nadoknaditi iznosi koje su uplatili društvu na ime uplate neuplaćenog udjela isključenog člana. Ono što preostane mora se koristiti za podmirenje onoga što još nije podmireno društvu na ime uplate uloga isključenog člana, a eventualni ostatak se isplaćuje tom članu (čl. 403. st. 2. ZTD).

Ako je društvo u stečaju, njegovi članovi solidarno odgovaraju za uplatu dijela temeljnog kapitala društva koji nije uplaćen, ako su te uplate potrebne za podmirenje vjerovnika. Zahtjev u ime društva postavlja stečajni upravitelj. Za tu odgovornost nije potrebno da stečajni upravitelj prije toga pristupi prodaji poslovnog udjela niti provede postupak s naslova odgovornosti članova društva za neuplatu udjela. Za uplatu dijela temeljnog kapitala društva koji nije uplaćen odgovaraju i pravni prednici članova društva pod uvjetima propisanima u čl. 401. ZTD-a (čl. 404. st. 1. ZTD). S obzirom na to da je obveza članova društva uplatiti društvu dio temeljnog kapitala koji nije uplaćen razmjerna njihovim poslovnim udjelima u društvu, oni

59 Ono ne mora pokušati prodati udio ako je očito da za njegovu kupnju neće biti interesa. Od tada ga ono više ne drži kao povjerenik za nekog drugog. Vidi u ibid., str. 215.

60 U njih se ne ubraja onaj član društva koji je kupio poslovni udio njegovom prodajom obavljenom nakon isključenja člana. Vidi u ibid., str. 215.-216.

${ }_{61}$ Npr. društvo ga nije prodalo trećoj osobi ili nekom od članova društva.

62 Ibid., str. 216.-217. 
Dr. sc. Dionis Jurić: Uplata novčanog uloga za preuzete poslovne udjele i pravne posljedice neuplate u... Zbornik radova Pravnog fakulteta u Splitu, god. 58, 4/2021, str. 1165-1184

imaju međusobno pravo regresa za iznose koje bi platili više od onoga što bi na njih otpalo prema razmjeru preuzetih udjela (čl. 404. st. 2. ZTD).$^{63}$

\section{PROBOJ PRAVNE OSOBNOSTI I POTKAPITALIZACIJA DRUŠTVA}

Već je ranije naznačeno da je društvo s ograničenom odgovornošću samostalna pravna osoba koja ima vlastitu imovinu te njome odgovara za svoje obveze. Osobna imovina članova društva je odijeljena od imovine društva te oni ne odgovaraju za njegove obveze. ${ }^{64}$ Od toga općeg pravila postoji izuzetak pri proboju pravne osobnosti društva kada će članovi društva odgovarati za obveze društva ako su zloupotrijebili svoju neodgovornost za obveze društva (čl. 10. st. 3. i 4. ZTD). ${ }^{65}$ Proboj pravne osobnosti je odraz načela savjesnosti i poštenja te zabrane zloupotrebe prava, a razvio se u angloameričkoj sudskoj praksi kao korektiv načela neodgovornosti članova društava kapitala. ${ }^{66}$

Pomoću proboja pravne osobnosti vjerovnici mogu izravno namiriti tražbine koje imaju prema društvu od njegovih članova. Vjerovnici moraju podići tužbu protiv članova društva te moraju dokazati njihovu zloupotrebu (čl. 10. st. 3. ZTD) ${ }^{67}$ Smatrat će se da postoji zloupotreba ako članovi društva: a) koriste društvo za postizanje cilja koji im je inače zabranjen, ${ }^{68}$ b) koriste društto da bi oštetili vjerovnike, ${ }^{69} \mathrm{c}$ ) ako protivno zakonu upravljaju imovinom društva kao da je njihova ${ }^{70}$ te d) ako u svoju korist ili u korist neke treće osobe umanjuju imovinu društva, iako su znali ili morali znati da ono neće moći podmiriti svoje obveze (čl. 10. st. 4. ZTD). ${ }^{71} \mathrm{U}$

63 Ibid., str. 217.-218.

64 Načelo se ograničene odgovornosti u pravu društava SAD-a prihvaća 1830., a u engleskom pravu 1855. godine. Francuski Trgovački zakonik iz 1807. godine uvodi načelo ograničene odgovornosti, a pod njegovim utjecajem se to načelo širi i u druge europske kontinentalne države. Vidi u Jurić, D., Odgovornost vladajućeg društva za obveze ovisnog društva u hrvatskom i usporednom pravu, Zbornik Pravnog fakulteta Sveučilišta u Rijeci, vol. 23, br. 2., 2002., str. 509.-510.

65 Radi se o tzv. jamstvenom proboju pravne osobnosti.

66 Iz angloameričkog prava je taj institut nakon Drugog svjetskog rata uveden u njemačku pravnu teoriju i sudsku praksu. U angloameričkom se pravu proboj pravne osobnosti razvio iz načela pravednosti. Vidi u Ivanjko; Kocbek; Prelič, op. cit. u bilj. 5, str. 158.-160.

67 Vjerovnici moraju dokazati postojanje namjere članova društva zloupotrijebiti svoju neodgovornost za obveze društva.

68 Između društva i ostvarenog cilja mora postojati objektivna uzročna povezanost, a između cilja i članova društva subjektivni odnos odgovornosti za ostvarivanje zabranjenog cilja. Vidi u Ivanjko; Kocbek; Prelič, op. cit. u bilj. 5, str. 161.-162.

69 Zloupotreba može biti posljedica miješanja imovine članova i društva ili miješanja interesa članova i društva. Pri miješanju imovine značajno je tzv. pravno odjeljivanje imovine društva i njegovih članova, što se očituje u jasnom vođenju podataka o imovini društva u poslovnim knjigama. Vidi u ibid., str. 162.

70 Time članovi društva uzrokuju štetu društvu, a posredno i njegovim vjerovnicima, jer društvo ne može ispuniti svoje obveze. Ova odredba pokriva sva štetna postupanja članova s imovinom društva, a koja su protivna zakonu, društvenom ugovoru i dobrim poslovnim običajima. Vidi u ibid., str. 163.

71 Uz ovu objektivnu i subjektivnu pretpostavku, mora se ispuniti i treća, a ta je da društvo nije sposobno ispuniti svoje obveze vjerovnicima. Loc. cit. 
ovim je slučajevima teret dokaza na tuženiku (članovima društva). ${ }^{72}$ Sudovi mogu i izvan ovih slučajeva ocjenjivati postoji li proboj pravne osobnosti u konkretnom slučaju. ${ }^{73}$ Vjerovnici će moći načelno lakše dokazati zloupotrebu članova društva s ograničenom odgovornošću, s obzirom da imaju manji broj članova, a oni mogu i neposredno utjecati na vođenje poslova društva (obvezatne upute skupštine (članova društva) upravi o vođenju poslova društva, društvo s jednim članom koji je i član uprave i sl.)..$^{74}$

Za obveze društva odgovara njegov član kojemu se dokaže zloupotreba. ${ }^{75}$ To ne mora biti osoba koja je član društva u vrijeme podizanja tužbe. ${ }^{76}$ Nije odlučno ni je li u vrijeme dok je tuženi bio član društva nastala ili dospjela obveza koja se ostvaruje tužbom. Član društva odgovara za sve obveze društva. ${ }^{77}$ Tužbu može podnijeti svaki vjerovnik, a ne samo onaj kojemu društvo ne može podmiriti obvezu. Dovoljno je da mu obveza nije podmirena. ${ }^{78}$

Odgovornost je članova društva solidarna ${ }^{79} \mathrm{i}$ neograničena, a zasnivanjem njihove odgovornosti ne prestaje odgovornost društva. ${ }^{80}$ Clan društva odgovara za tuđu obvezu te je njegova odgovornost akcesorna ${ }^{81}$ Vjerovnik može birati hoće li zahtjev postaviti samo protiv društva ili protiv društva i svih njegovih članova, društva i nekih članova ili samo protiv članova, odnosno samo protiv nekih članova društva. Pritom se mora dokazati zloupotreba članova društva, a nije odlučno je li društvo sposobno podmiriti obvezu ili to odbija učiniti. Za podizanje je tužbe dovoljno da je obveza društva dospjela i da nije podmirena, odnosno da nije uredno podmirena. ${ }^{82}$ Član društva može protiv vjerovnikovog zahtjeva istaknuti sve prigovore društva

72 Radi se o kvalificiranim slučajevima proboja pravne osobnosti. Tada tuženik dokazuje da nije bilo zloupotrebe njegove neodgovornosti za obveze društva.

73 Barbić, op. cit. u bilj. 3, str. 299.

74 Barbić, op. cit. u bilj. 8, str. 24.

75 To mogu biti fizičke i pravne osobe, većinski i manjinski članovi, članovi društva koji su istodobno i članovi uprave ili nadzornog odbora društva. To može biti jedan ili više članova društva.

76 Tuženi bi mogao biti i bivši član društva, ali i osoba koja je postala član nakon podizanja tužbe.

77 Odgovara u punom iznosu obveze, bez obzira na njezinu vrstu i pravni temelj.

78 Ibid., str. 25.

79 Takvu bi odgovornost trebalo primijeniti samo ako se utvrdi da su svi članovi društva jednako doprinijeli nastanku razloga za proboj pravne osobnosti. Pri ocjeni odgovornosti svakog člana društva valja posebno ocijeniti postojanje subjektivnih elementa (namjera, znanje, odnosno dužnost znanja). Osobito treba uzeti u obzir: a) stupanj njihove uključenosti u poslovanje društva, b) njihov utjecaj na vođenje poslova i njihovo sudjelovanje u tome, c) stupanj upoznatosti s poslovanjem društtva, d) kakav je uopće bio njihov interes sudjelovati u društvu (samo sudjelovanje u podjeli dobiti, aktivno sudjelovanje pri upravljanju ili vođenju poslova) te e) jesu li stekli korist od društva na nedopušteni način. Vidi u Kocbek, M. et al., Veliki komentar Zakona o gospodarskih družbah, 1. knjiga, GV Založba, Ljubljana, 2006., str. 166.

80 Radi se o solidarnom jamstvu. Vidi u Barbić, op. cit. u bilj. 8, str. 27.-28.

${ }_{81}$ Ako se utvrdi zloupotreba člana, njegova odgovornost postaje primarna te ne može prigovoriti vjerovniku da se prvo mora pokušati namiriti od društva.

82 Ibid., str. 26.-27. 
dužnika koji nisu strogo osobne naravi, ${ }^{83}$ a može istaknuti i svoje prigovore ${ }^{84}$ Član koji ispuni obvezu društva ima pravo regresa prema društvu, a supsidijarno i prema drugim članovima koji su odgovorni za proboj. ${ }^{85}$

Do proboja pravne osobnosti može dovesti potkapitalizacija društva. Članovi slobodno odlučuju o izvorima pribavljanja (vlastiti ili tuđi kapital) i količini kapitala koji je potreban društvu za ostvarivanje njegovih ciljeva, a pri čemu su vezani samo odredbama o najnižem iznosu temeljnog kapitala društva s ograničenom odgovornošću. Pod potkapitalizacijom se podrazumijeva imovinsko stanje društva koje onemogućava ostvarivanje njegovih gospodarskih ciljeva. ${ }^{86}$ Ona može biti nominalna i materijalna. Kod nominalne potkapitalizacije društvo može pribaviti potrebni kapital uzimanjem kredita (pribavljanje tuđeg kapitala). Ona nije podloga za proboj pravne osobnosti, a vjerovnici se štite odredbama ZTD-a samo kada se radi o zajmovima članova društva. ${ }^{87}$ Kod materijalne potkapitalizacije društvo nema sredstava za redovito poslovanje, pri čemu ne može pribaviti ni tuđi kapital. Ona može biti osnova za proboj pravne osobnosti, ako je posljedica postupanja članova društva. Pravna podloga za to je odredba čl. 10. st. 4. t. 4. koja određuje da odgovornost članova za obveze društva postoji ako oni u svoju korist ili u korist neke treće osobe umanje imovinu društvu, iako su znali ili morali znati da ono neće moći podmiriti svoje obveze ${ }^{88}$ Odgovornost će postojati i ako nisu osigurali dovoljno kapitala za poslovanje društva. Za utvrđivanje odgovornosti članova za obveze društva u slučaju materijalne potkapitalizacije bit će značajno jesu li oni pri osnivanju društva i odlučivanju o njegovoj kapitalizaciji postupali kao dobri gospodarstvenici. Ako su članovi osnovali društvo, a znali su ili su morali znati da temeljni kapital nije dovoljan za normalno poslovanje društva i da njegovi vjerovnici mogu biti oštećeni, postoji opravdani razlog za primjenu proboja pravne osobnosti. ${ }^{89}$ Materijalna potkapitalizacija osobito prijeti jednostavnim društvima s ograničenom odgovornošću, pri čemu se to nastoji spriječiti obvezom hitnog sazivanja skupštine radi dokapitalizacije društva, ako mu prijeti nesposobnost za plaćanje (čl. 390.a st. 6. ZTD) te obvezom oblikovanja zakonskih rezervi koje se mogu koristiti samo za

83 Npr. nevaljanost nastanka obveze, obveza nije dospjela, prestanak obveze, zastara zahtjeva vjerovnika, prijeboj i sl.

84 Npr. prigovori kojima se pobija postojanje zloupotrebe, zastare vjerovnikovog zahtjeva prema članu društva, prijeboja vlastite tražbine s tražbinom vjerovnika prema društvu, napuštanja ili gubitka osiguranja tražbine koju je vjerovnik imao za ispunjavanje i sl. Vidi u ibid., str. 29.-30.

85 Širola, op. cit. u bilj. 34, str. 1719.-1720.

86 Od potkapitalizacije valja razlikovati insolventnost (nesposobnost za plaćanje) i prezaduženost, koji mogu biti razlozi za otvaranje stečajnog postupka.

87 Čl. 408. ZTD-a o zajmu člana društva kojim se nadomješta vlastiti kapital društva. Vidi u Barbić, op. cit. u bilj. 3, str. 305., Ivanjko; Kocbek; Prelič, op. cit. u bilj. 5, str. 164.

88 Radi se o slučajevima izvlačenja sredstava iz društva, čime se mogu oštetiti njegovi vjerovnici. Vidi u Barbić, op. cit. u bilj. 3, str. 305.

89 Ivanjko; Kocbek; Prelič, op. cit. u bilj. 5, str. 164. 
pokriće gubitaka i nominalno povećanje temeljnog kapitala (čl. 390.a st. 5. ZTD). ${ }^{90}$ Time se posredno štite vjerovnici društva. ${ }^{91}$

\section{ZAKLJUČAK}

Izmjenama i dopunama ZTD-a iz 2019. godine olakšava se uplata novčanih uloga za preuzete poslovne udjele propisivanjem da prije upisa osnivanja društva u sudski registar svaki član društva mora uplatiti najmanje četvrtinu uloga za preuzeti poslovni udio, pri čemu ukupni iznos svih novčanih uplata ne može biti manji od jedne četvrtine temeljnog kapitala. Ako članovi osnivaju društvo s najnižim propisanim iznosom temeljnog kapitala, to bitno smanjuje iznos početnih sredstava koje moraju uplatiti društvu. Pritom se propisuje i krajnji rok za uplatu ostatka novčanog uloga od jedne godine od dana upisa društva u sudski registar. Sve dok član društva ne uplati svoj novčani ulog u cijelosti, odgovara za obveze društva osobno i solidarno sa svim drugim članovima koji nisu uplatili uloge do visine iznosa neuplaćenih uloga za sve poslovne udjele u društvu. Propisivanjem krajnjeg roka za uplatu novčanih uloga potire se sloboda članova odrediti društvenim ugovorom ili svojom odlukom dospijeće uplate preostalog novčanog uloga. Još je spornije uvođenje osobne i ograničene odgovornosti članova za obveze društva, a koji nisu uplatili u cijelosti svoje uloge za preuzete poslovne udjele. Time se narušava temeljno načelo neodgovornosti članova za obveze društva i načelo odvojenosti društva od njegovih članova kao zasebnih pravnih subjekata. Društvo s ograničenom odgovornošću spada u društva kapitala kojima je temeljna značajka neodgovornost članova za obveze društva. Iako je u njemu prisutan i personalni element, ${ }^{92}$ uvođenjem osobne i ograničene odgovornosti za obveze društva, ako ulozi nisu uplaćeni u cijelosti, pridaju mu se značajke trgovačkih društava osoba. Takvo uređenje ne postoji u usporednom pravu koje je bilo uzor pri donošenju ZTD-a.

Obveza uplate novčanih uloga za preuzete poslovne udjele tiče se samo odnosa društva i njegovih članova. Pritom su vezani odredbama ZTD-a o najnižem iznosu uloga kojega moraju uplatiti prije upisa osnivanja ili povećanja temeljnog kapitala društva ${ }^{93}$ te odredbama o najnižem iznosu temeljnog kapitala. To proizlazi i iz pravnih posljedica koje propisuje zakon ako zakasne s uplatom uloga: plaćanje zateznih kamata, mogućnost provedbe postupka isključenja člana iz društva zbog zakašnjenja s uplatom uloga, odgovornost njegovih pravnih prednika za uplatu,

90 Obvezom oblikovanja zakonskih rezervi ograničava se i iznos dobiti koji je podoban za isplatu dividende članovima društva.

91 Ivkošić, op. cit. u bilj. 19, str. 564.-568.

92 Npr. široke mogućnosti ograničenja prijenosa poslovnih udjela, utjecaj na vođenje poslova društva, odgovornost ostalih članova za uplate društvu, ako to ne učini određeni član, veća sloboda urediti unutarnje ustrojstvo i njihove međusobne odnose u društvu društvenim ugovorom, pravo na actio pro socio i sl.

93 Iznimka su jednostavna društva s ograničenom odgovornošću i društva koja pružaju financijske usluge, kada je posebnim propisima određena uplata novčanih uloga u cijelosti prije upisa tih činjenica u sudski registar. 
prodaja poslovnog udjela isključenog člana te odgovornost ostalih članova za uplatu uloga isključenog člana. Društvo može utužiti dospjelu obvezu člana na uplatu ostatka uloga, a o provedbi kaduciranja slobodno odlučuje.

Interesi društva, a posredno i interesi vjerovnika štite se odredbama ZTD-a kojima se ostvaruje načelo unosa i održavanja temeljnog kapitala. Vjerovnicima se iznimno pruža zaštita ako bi smanjenjem imovine društva bilo ugroženo namirenje njihovih tražbina. Tako oni mogu postaviti zahtjeve za naplatom svojih tražbina članovima uprave koji nisu postupali s dužnom pozornošću pri vođenju poslova, kada to ne mogu učiniti iz imovine društva. ${ }^{94}$ Pri redovitom smanjenju temeljnog kapitala društva vjerovnici mogu od društva tražiti naplatu svojih dospjelih tražbina, odnosno osiguranje za svoje nedospjele tražbine. ${ }^{95}$ Eventualna odricanja društva od zahtjeva za naknadu štete te nagodbe o tome u slučaju odgovornosti članova uprave i članova društva za štetu u postupku osnivanja ne djeluju prema vjerovnicima, ako je ispunjenje obveze naknade štete potrebno za njihovo namirenje. ${ }^{96}$ Ako je član društva primio isplatu dividende u dobroj vjeri, a radi se o nedopuštenom primanju, mora ju vratiti ako je to potrebno za namirenje vjerovnika. Vjerovnici mogu svoje tražbine i inače osigurati pri sklapanju ugovora s društvom, a interesi im se štite tijekom likvidacije društva te u eventualnom stečaju nad društvom.

Iznimka od neodgovornosti članova za obveze društva postoji samo u slučaju proboja pravne osobnosti. To je krajnje sredstvo koje će vjerovnici koristiti da bi naplatili svoje tražbine prema društvu od njegovih članova. Pritom moraju dokazati zloupotrebu članova da ne odgovaraju za obveze društva, a u kvalificiranim slučajevima proboja pravne osobnosti položaj im je olakšan prebacivanjem tereta dokaza na tuženike (članove društva). Proboj pravne osobnosti dolazi u obzir samo ako se radi o materijalnoj potkapitalizaciji društva.

94 Zahtjev za naknadu štete prema članovima uprave je akcesoran u odnosu na zahtjev društva zbog propusta članova uprave u vođenju poslova društva. To vrijedi samo u slučajevima grube povrede dužnosti postupati s pozornošću urednog i savjesnog gospodarstvenika i u slučajevima iz čl. 252. st. 3. ZTD-a (čl. 430. ZTD).

95 To vrijedi i prilikom priključenja društva.

96 To vrijedi i prilikom odgovornosti članova uprave za štetu počinjenu društvu. 


\section{LITERATURA}

1. Barbić, J., Pravo društava, Knjiga prva: Opći dio, Organizator, Zagreb, 2008.

2. Barbić, J., Pravo društava, Knjiga druga: društva kapitala, Svezak I.: dioničko društvo, Organizator, Zagreb, 2010.

3. Barbić, J., Pravo društava, Knjiga druga: društva kapitala, Svezak II.: društvo s ograničenom odgovornošću, društvo za uzajamno osiguranje, kreditna unija, Organizator, Zagreb, 2010.

4. Bogdanović, O., Dodatne činidbe u društvu s ograničenom odgovornošću, Pravnik, vol. 46, br. 93., 2013., str. 149.-165.

5. Ivanjko, Š.; Kocbek, M; Prelič, S., Korporacijsko pravo, GV Založba, Ljubljana, 2009.

6. Ivkošić, M., Društvo s ograničenom odgovornošću u svjetlu novele Zakona o trgovačkim društvima iz 2019., Zbornik radova Pravnog fakulteta u Splitu. god. 57, br. 2., 2020., str. 551.-583.

7. Ivkošić, M., Kapitalno orijentirani sustav zaštite vjerovnika društva s ograničenom odgovornošću, Zbornik Pravnog fakulteta u Zagrebu, vol. 70, br. 1., 2020., str. 107.135.

8. Jurić, D., Odgovornost vladajućeg društva za obveze ovisnog društva u hrvatskom i usporednom pravu, Zbornik Pravnog fakulteta Sveučilišta u Rijeci, vol. 23, br. 2., 2002., str. 507.-541.

9. Kocbek, M. et al., Veliki komentar Zakona o gospodarskih družbah, 1. knjiga, GV Založba, Ljubljana, 2006.

10. Schmidt, S., Austria’s Limited Liability Companies: „Less Light“, http://roadmap2015. schoenherr.eu/austrias-limited-liability-companies-less-light/, 7. kolovoza 2020.

11. Širola, N., Odgovornost članova društva s ograničenom odgovornošću za nedopušten zahvat u imovinu društva, Zbornik Pravnog fakulteta u Zagrebu, vol. 61, br. 5., 2011., str. 1687.-1728.

12. Zakon o trgovačkim društvima, Narodne novine, br. 111/1993, 34/1999, 121/1999, 52/2000, 118/2003, 107/2007, 146/2008, 137/2009, 125/2011, 152/2011, 111/2012, $68 / 2013,110 / 2015,40 / 2019$. 


\section{PAYMENT OF CASH CAPITAL CONTRIBUTION FOR SHARES AND LEGAL CONSEQUENCES OF ITS NON-PAYMENT IN LIMITED LIABILITY COMPANY}

By amendments of the Companies Act in 2019 payment of cash capital contributions for shares was facilitated in limited liability companies. Before registration of the company each shareholder must pay at least one quarter of the nominal value of each share and total amount of all payments must be equal to one quarter of the company share capital. The Companies Act sets payment duty of the rest of cash contributions in term of the one year after the company registration. It introduces personal, joint and several liabilities of shareholders who did not pay contributions in full for company debts up to the amount of unpaid contributions for all shares. This limits the freedom of shareholders to determine payment deadline for cash contributions and endangers the non-liability of shareholders for company debts. Creditors' interests are appropriately protected by rules on payment of capital contributions and on protection of the company share capital. They are specially protected in cases of reduction of company assets which endanger fulfilment of their claims. This paper deals with legal consequences of non-payment of contributions in cash and measures which company may take against its shareholder. Creditors may directly fulfil their claims against shareholders only in cases of the piercing of the corporate veil, and especially if there is an evidence of the company undercapitalization.

Key words: Limited Liability Company, payment of cash contribution, legal consequences of non-payment, piercing of the corporate veil 